\title{
Revision of the subgenus Tinotus Sharp, stat. $n$., of the parasitoid rove-beetle genus Aleochara Gravenhorst (Coleoptera, Staphylinidae, Aleocharinae) from Japan, Taiwan, and the Russian Far East
}

\author{
Shûhei Yamamoto ${ }^{1,3}$, Munetoshi Maruyama²
}

I Entomological Laboratory, Graduate School of Bioresource and Bioenvironmental Sciences, Kyushu University, Hakozaki 6-10-1, Higashi-ku, Fukuoka 812-8581, Japan 2 The Kyushu University Museum, Hakozaki 6-10-1, Higashi-ku, Fukuoka 812-8581, Japan 3 Japan Society for the Promotion of Science Research Fellow (DC), Japan

Corresponding author: Shûhei Yamamoto (s.yamamoto.64@gmail.com)

Academic editor:J. Klimaszewski | Received 5 October 2015 | Accepted 14 December 2015 | Published 3 February 2016

http://zoobank.org/2E4E9D73-C921-4E82-B2E8-864C995F1CD2

Citation: Yamamoto S, Maruyama M (2016) Revision of the subgenus Tinotus Sharp, stat. n., of the parasitoid rovebeetle genus Aleochara Gravenhorst (Coleoptera, Staphylinidae, Aleocharinae) from Japan, Taiwan, and the Russian Far East. ZooKeys 559: 81-106. doi: 10.3897/zookeys.559.6755

\begin{abstract}
The subgenus Tinotus Sharp, 1833, stat. n., of the genus Aleochara Gravenhorst, 1802 (Aleocharini: Aleocharina) from Japan, Taiwan, and the Russian Far East is revised. Tinotus is a new record from the latter two regions. Three species are recognized: Aleochara (Tinotus) morion Gravenhorst, 1802, comb. n. [Japan (new record), the Russian Far East (new record)], A. (T.) eoa nom. n. [replacement name for Tinotus japonicus Cameron, 1933; Japan, Taiwan (new record)], and $A$. (T.) takashii sp. n. (central Honshû, Japan). The systematic position of Tinotus is discussed. All species are (re-)described, keyed, and figured. A world checklist of Tinotus species, comprising 40 valid species, is provided in an appendix. Additional taxonomic changes are proposed, including a new synonymy, a revalidation, 13 new replacement names, and 27 new combinations.
\end{abstract}

\section{Keywords}

Aleocharini, new species, new combinations, revalidation, replacement names, checklist, East Asia, Palaearctic Region 


\section{Introduction}

The rove-beetle genus Aleochara Gravenhorst, 1802 (Aleocharinae: Aleocharini, Aleocharina) is distributed worldwide, except in Antarctica (Klimaszewski 1984). This genus is the most speciose genus of the tribe Aleocharini, with approximately 500 species in 18 subgenera. Aleochara is likely a monophyletic group based on extensive molecular analyses (Maus et al. 2001).

On the other hand, the genus Tinotus Sharp, 1883 has recently been recognized as phylogenetically close to, or a possible member of, Aleochara (Maus et al. 2001; Hanley 2002; Osswald et al. 2013). Its taxonomic placement, including its tribal assignment, has been controversial for a long time, mainly due to its tarsal formula (4-55; see Hanley 2002). According to Maus et al. (2001), Tinotus is a taxon that should be considered within the genus Aleochara. The distributional range of Tinotus is quite wide, as it has been recorded from every zoogeographic region, except the Australian Region, with approximately 40 species (Hanley 2002; Klimaszewski et al. 2002).

Larvae of Aleochara and Tinotus act as ectoparasitoids on cyclorrhaphous Diptera, and the adults prey upon dipteran eggs and larvae (e.g., Klimaszewski 1984; Maus et al. 1998). Thus, they have been considered potential candidates for classic biological control of commercial crops against pest flies in Europe and North America (e.g., White and Legner 1966; Fournet et al. 2000).

Taxonomic knowledge of Tinotus in East Asia is still incomplete. In Japan, Taiwan, and the Russian Far East, just one species, Tinotus japonicus Cameron, 1933, has been originally described from Japan. In this study, we (re-)describe three Tinotus species distributed in these regions. We discuss the systematic position of Tinotus. We also provide a complete Tinotus species list, reflecting recent species additions, synonyms, and corrections.

\section{Material and methods}

We used the technical procedures and methods used by Maruyama (2006) and Yamamoto and Maruyama (2012). The terminology used for this study generally follows that of Hanley (2002), Klimaszewski et al. (2002), and Yamamoto and Maruyama (2012, 2013). For chaetotaxy of the mouthparts we followed Sawada $(1972,1987)$. We followed Welch (1997) for genital terminology, especially that of females. In the descriptions, the number of macrosetae on tergite VIII and sternite VIII refers to one side of the body. Furthermore, minute setae were omitted or depicted only for one side of the body.

Abbreviations for measurements: BL, length of the body from clypeus to apex of the abdomen; EW, maximum width both elytra combined; HL, maximum length of the head; HW, maximum width of the head; PL, maximum length of the pronotum; PW, maximum width of the pronotum along midline.

Other abbreviations: BRL, blue round label pinned by a curator; HW, handwritten. 
The following acronyms of museums and private collections are used throughout the text:

BMNH Natural History Museum, London, U.K. (R. Booth);

FMNH Field Museum of Natural History, Chicago, U.S.A. (R. Baquiran);

HUM Hokkaido University Museum (M. Ôhara);

KUM Kyushu University Museum, Fukuoka, Japan (M. Maruyama);

PCTW Private collection of Mr. Takashi Watanabe (Kanagawa, Japan).

\section{Taxonomy}

\section{Genus Aleochara Gravenhorst, 1802}

\section{Subgenus Tinotus Sharp, 1883, stat. n.}

Tinotus Sharp, 1883: 170. Type species: Tinotus cavicollis Sharp, 1883. Fixed by Fenyes 1918: 25, by subsequent designation.

Exaleochara Keys, 1907: 102. Type species: Tinotus morion Gravenhorst, 1802. Fixed by Klimaszewski et al. 2002: 284, by monotypy. As synonym of Tinotus: e.g., Bernhauer \& Scheerpeltz 1926: 713; Blackwelder 1952: 163; Ashe 2000: 360; Hanley 2002: 457; Klimaszewski et al. 2002: 284; Gouix and Klimaszewski 2007: 30; Schülke and Smetana 2015: 505.

Acrimea Casey, 1911: 14. Type species: Acrimea resecta Casey, 1911. Fixed by Fenyes 1918: 20, by subsequent designation. Synonymized by Gusarov 2003: 353 .

See further references in Hanley (2002), Klimaszewski et al. (2002), and Gusarov (2003).

Diagnosis. This subgenus is rather easily distinguished from the other congeneric taxa by 1) compact, small ( $<4 \mathrm{~mm}$ ), and 2) strongly spindle-shaped body; 3) 4-5-5 tarsal formula (5-5-5 in the other subgenera of Aleochara); 4) fully carinate mesoventrite; 5) wide and 6) truncate apex of intercoxal process of mesoventrite, 7) and its apex reaching to apex of intercoxal process of metaventrite; 8) median lobe of aedeagus with developed flagellum; 9) female spermatheca without apical invagination of spermathecal head (sensu Welch 1997) and, 10) coiled basally. Minute characters on mouthparts probably define the subgenus as well, e.g., setula $a$ on the first segment of labial palpi located at nearly apical margin of the segment (Fig. 5; see also Sawada 1987).

Remarks. See other characters mentioned in detail by Hanley (2002) and Klimaszewski et al. (2002).

Systematic position. Sharp's (1833) original description of Tinotus placed this taxon in the group Myrmedoniina (= Lomechusini) due to its 4-5-5 tarsal formula. Since, Tinotus has also been placed in Hoplandriini (e.g., Seevers 1978) or Aleocharini 
(e.g., Lohse 1974), mainly based on the presence of a pseudosegment on the maxillary and labial palpi (see Hanley 2002 for a historical review).

In contrast to these ambiguities, recent studies have refuted all tribal placements other than Aleocharini. Hanley (2002) recognized Tinotus within Aleocharini, suggesting a close relationship with the genus Aleochara, based on the seven shared morphological characteristics of the genus, e.g., bifid to crescent-shaped apex of the ligula. According to the extensive molecular study of Aleochara by Maus et al. (2001), Tinotus was fully resolved within the "bilineata clade" of Aleochara. Similarly, Osswald et al. (2013), who used significantly fewer species (only four species of Aleochara, one of which is Tinotus) but analyzed them with much more molecular markers (4599 bp), also supported the assignment of Tinotus to Aleochara.

In our morphological study of Tinotus and Aleochara species, we found numerous morphological similarities between these genera, including a long intercoxal process of mesoventrite, except for the 4-5-5 tarsal segmentation in Tinotus (5-5-5 in Aleochara). Among the subgenera of Aleochara, Tinotus shares characters with the subgenus Xenochara Mulsant \& Rey, 1874 , i.e., carinate mesoventrite and fusiform body (including convexed pronotum). Remarkably, the subgenus Coprochara Mulsant \& Rey, 1874 seems to be significantly more closely related to Tinotus. In fact, they share some important characters, including a completely carinate mesoventrite and a coiled spermatheca (Yamamoto and Maruyama 2013). Maus et al. (2001) also implied that both subgenera are phylogenetically close to Tinotus. Reduction of the antennal segment or tarsal segmentation in Aleocharinae is associated rather frequently with miniaturization of their body size (e.g., tribes Hypocyphtini and Mesoporini), and Tinotus species are possibly no exception. Therefore, no significant character exists to distinguish Tinotus from Aleochara at the genus level. We herein transfer Tinotus, as the 19th subgenus, to the genus Aleochara.

\section{Aleochara (Tinotus) morion Gravenhorst, 1802, comb. n.}

Figs 1, 4-19, 36

Aleochara morion Gravenhorst, 1802: 97 (original description).

Tinotus morion: Seevers 1978: 196 (male genitalia figured); Hanley 2002: 463 (catalogue of world species of Tinotus); Klimaszewski et al. 2002: 285 (key to Nearctic species of Tinotus), 294 (redescription); Smetana 2004: 362 (catalogue of Palearctic species of Aleocharinae); Gouix and Klimaszewski 2007: 30 (catalogue of Canadian and Alaskan species of Aleocharinae), 149 (dorsal habitus photographed); Klimaszewski et al. 2013: 16 (catalogue of Canadian Staphylinidae), 60 (redescription), 247 (dorsal habitus photographed), 273 (male and female genitalia figured); Schülke and Smetana 2015: 506 (catalogue of Palearctic species of Aleocharinae). See other references and synonymies in Hanley (2002) and Klimaszewski et al. (2002).

Type locality. Braunschweig, Germany. 
Non-type material examined. JAPAN: Hokkaidô: 1 male, Nemuroshibetsu, Shibetsu-chô, 18.vii.1977, S.-I. Naomi leg. (KUM); 1 male, Lake Toro, Shibecha, 27.vii.1986, S. Nomura leg. (KUM); 1 male, 3 spec., Kamishumbetsu, Betsukaichô, 20.vii.1977, S.-I. Naomi leg. (KUM); 1 male, Mt. Mashû-dake (just below the summit), 820 m, Teshikaga-chô, 15.vii.1990, sweeping of Carex-grass, K. Haga leg. (KUM); 1 female, Shiretoko-tôge Pass, Rausu-chô, 3.viii.1989, bottom of gutter on roadside, K. Haga leg. (KUM); 1 male, 1 spec., Sakae-machi, Oshidomari, Rishirifuji-chô, S.-I. Naomi leg. (KUM); 2 females, 1 spec., Nukanan Dam (right bank), Memuro, Ashoro-chô, 30.vii.1988, human excrement, K. Haga leg. (KUM); 1 male, 1 female, 7 spec., Shihoro, Kamishihoro-chô, GPS 4332'03.9”N, 14309'58.5”E, 13.vii.2014, bear dung, S. Yamamoto leg. (KUM); 2 males, 1 female, 1 spec., Obihiroshi, 6.vi.1980, H. Togawa leg. (KUM); 2 spec., Obihiro-shi, 7.vii.1980, H. Togawa leg. (KUM); Honshû: 1 female, Inashiki, Ibaraki-ken, 29.iv.1983, S. Ohmomo leg. (KUM); 1 male, Sugaya, Ranzan-machi, Saitama-ken, 10.iv.1994, K. Toyoda leg. (KUM); 1 female, Mt. Gagyû-san, Takahashi-shi, Okayama-ken, 29.v.1977, S.-I. Naomi leg. (KUM). RUSSIA: Far East: 1 male, Maltsevskaya Cape, Churkin, Vladivostok, Primorsky, 22.vi.1997, human excrement, M. Ôhara leg. (HUM).

Reference material examined. AUSTRIA: Niederösterreich: 1 spec., "Ulrichskirchen / N. Ö., J. Spurny // morion [HW] / grh. [HW] // Chicago NHMus / M. Bernhauer / Collection" (FMNH); ITALY: Calabria: 1 spec., "Calabria / Cimina / lg. Paganetti // morion [HW] / grh. [HW] / det. Bernh. // Chicago NHMus / M. Bernhauer / Collection" (FMNH).

Diagnosis (see Klimaszewski et al. 2002). This species can be distinguished from most members of the subgenus Tinotus by the following combination of characters: body entirely black, rarely light brown (Fig. 1); median lobe of aedeagus of male with a basal protuberance in lateral view (Fig. 16: arrow); spermatheca with a simple and oblong spermathecal head, equally serrate inner walls inside spermathecal head, and with four coils at base (Fig. 19). Aleochara morion is extremely similar to $A$. (T.) rougemonti (Pace, 1993), comb. n. from China, including male-female genital structures, but the former species is discriminated from the latter by having longer sclerites inside a median lobe of the male aedeagus (Pace 1993: Fig. 160), and by having four coils of the female spermatheca ( $A$. rougemont $i$ with two coils; Pace 1993: fig. 162).

Redescription. Measurements (in $\mathrm{mm}, \mathrm{n}=30): \mathrm{BL}=2.448(1.777-2.996) ; \mathrm{HL}=$ $0.382(0.315-0.453) ; \mathrm{HW}=0.392(0.332-0.451) ; \mathrm{PL}=0.421(0.355-0.485) ; \mathrm{PW}=$ $0.632(0.518-0.724) ; \mathrm{EW}=0.737(0.595-0.853)$.

Body (Fig. 1): fusiform, compact, and robust; dorsal surface moderately glossy and pubescent, covered with large micro-reticulation. Color (Fig. 1): usually uniformly black to blackish brown; antennomeres I-III dark brown, but segments IV to X darker with numerous minute whitish setae; mouthparts and legs yellowish brown to brown; pubescence yellowish brown to brown.

Head (Fig. 1): subquadrate, as long as width $(\mathrm{HW} / \mathrm{HL}=1.03, \mathrm{n}=30)$, widest at just behind eyes; setae on vertex rather dense, directed anteriomedially. Eyes: small, occupying approximately one third of head length, very slightly protruding laterally. 

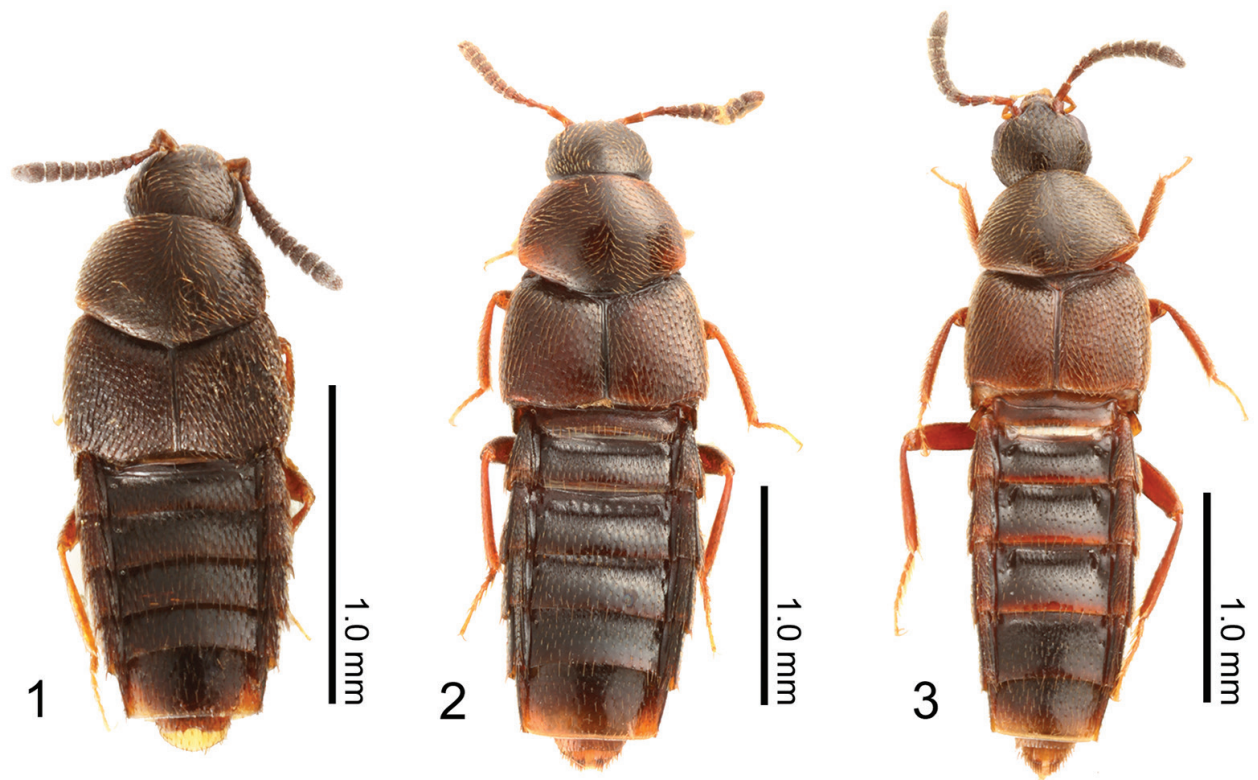

Figures I-3. Dorsal habitus of Japanese species of Aleochara (Tinotus): I Aleochara (Tinotus) morion 2 A. (T.) eoa 3 A. (T.) takashii.

Mouthparts (Figs 5-8): labrum (Fig 7) moderately transverse, approximately 1.70 times as wide as long (excluding basal apodeme), anterior margin slightly emarginate medially, basal apodeme semi-transparent; surface with pseudopores scattered scarcely. Labial palpus (Fig. 5): setula $a$ well-developed, situated near apical margin of labial palpomere I, while that of $b$ and $c$ strongly reduced. Maxilla (Fig. 6): lacinia with a distal comb consisting of dense-thin spines; galea rather short, as long as maxillary palpomere II; maxillary palpomere IV narrow and short, less than half length of that of III. Mentum (Fig. 8): anterior margin broadly emarginate.

Antennae (Fig. 4): short, moderately shorter than head and pronotum combined; thick, setaceous, becoming gradually and slightly broaden apically in segments IV to $\mathrm{X}$, with segments IV to X clearly transverse; segment XI symmetrical, obtusely pointed at apex; approximate relative length of segments from basal to apex: 22: 14: 16: 5: 5: 5: 6: 6: 7: 7: 19 .

Pronotum (Fig. 11): convex above dorsally, transverse (PW/PL $=1.50, \mathrm{n}=30$ ), moderately longer than sutural length of elytra, widest around below of basal half, basal margin weakly rounded; pubescence rather long, dense, directed laterally and posterolaterally; micro-reticulation conspicuous.

Mesoventrite (Fig. 9): completely carinate along midline; inter coxal process broadly elongate, with truncate apex, completely reaching to inter coxal process of metaventrite.

Elytra (Figs 1, 10): together, transverse, rather small, widest at middle; pubescence short, finely scattered densely, diverging posterolaterally in each elytron; dorsal surface rough, somewhat deeply impressed; posterolateral corner of each elytron moderately sinuate. 

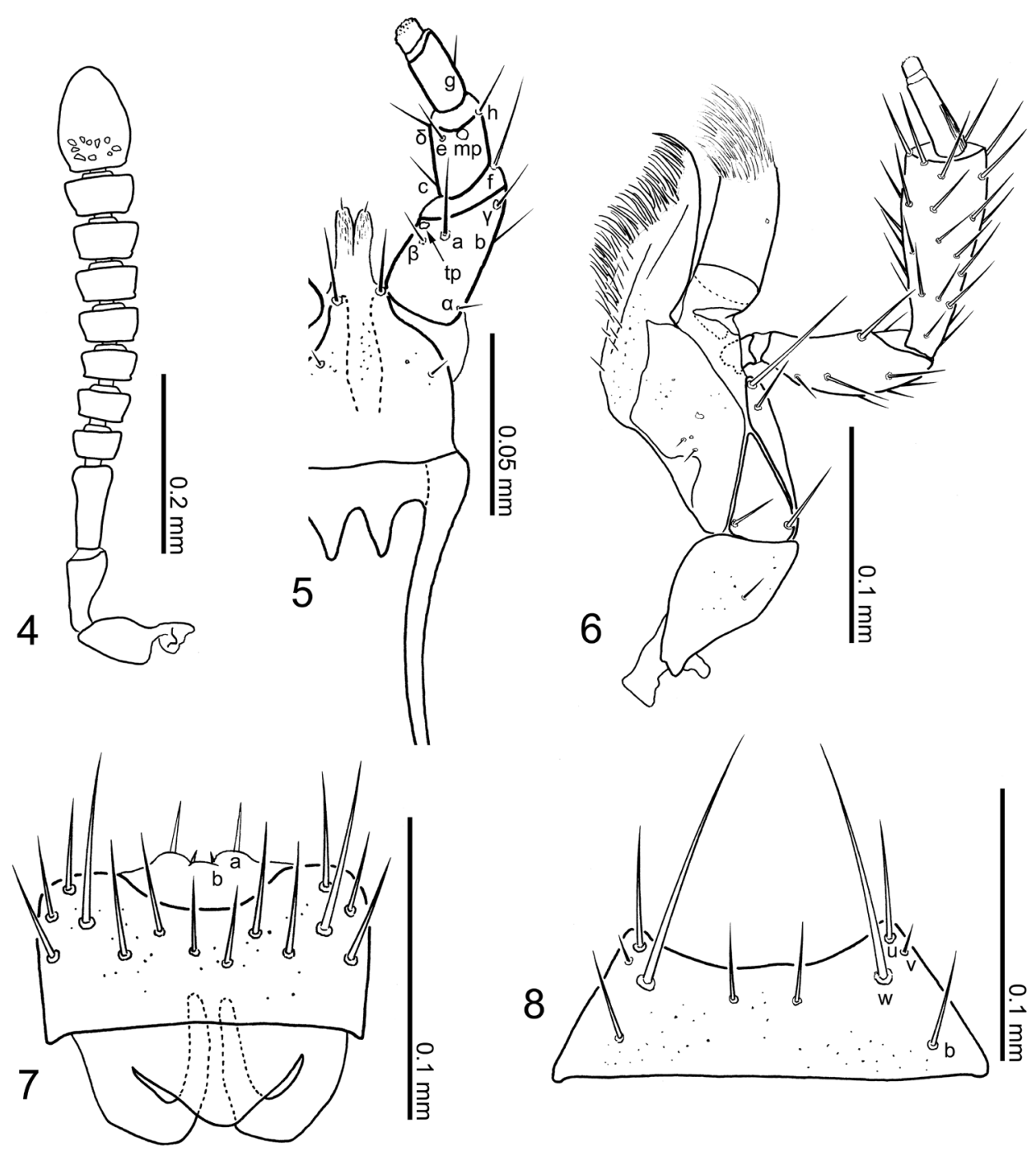

Figures 4-8. Body parts of Aleochara (Tinotus) morion of male: $\mathbf{4}$ right antenna 5 labium $\mathbf{6}$ maxilla 7 labrum 8 mentum.

Legs (Fig. 1): simple, short and, moderately slender; fore and midtibia with dozens of undeveloped spines, respectively.

Abdomen (Fig. 1): first three visible tergites rather shallowly impressed transversely at base; dorsal and ventral surface covered with setae densely.

Male. Tergite VIII (Fig. 12): basal suture fully developed (see Maruyama 2006: 20); posterior margin very weakly serrate, insignificantly emarginate medially; dorsal surface covered with setae rather densely, with five macrosetae. Sternite VIII (Fig. 14): basal suture fully developed; posterior margin very weakly pointed; ventral surface cov- 

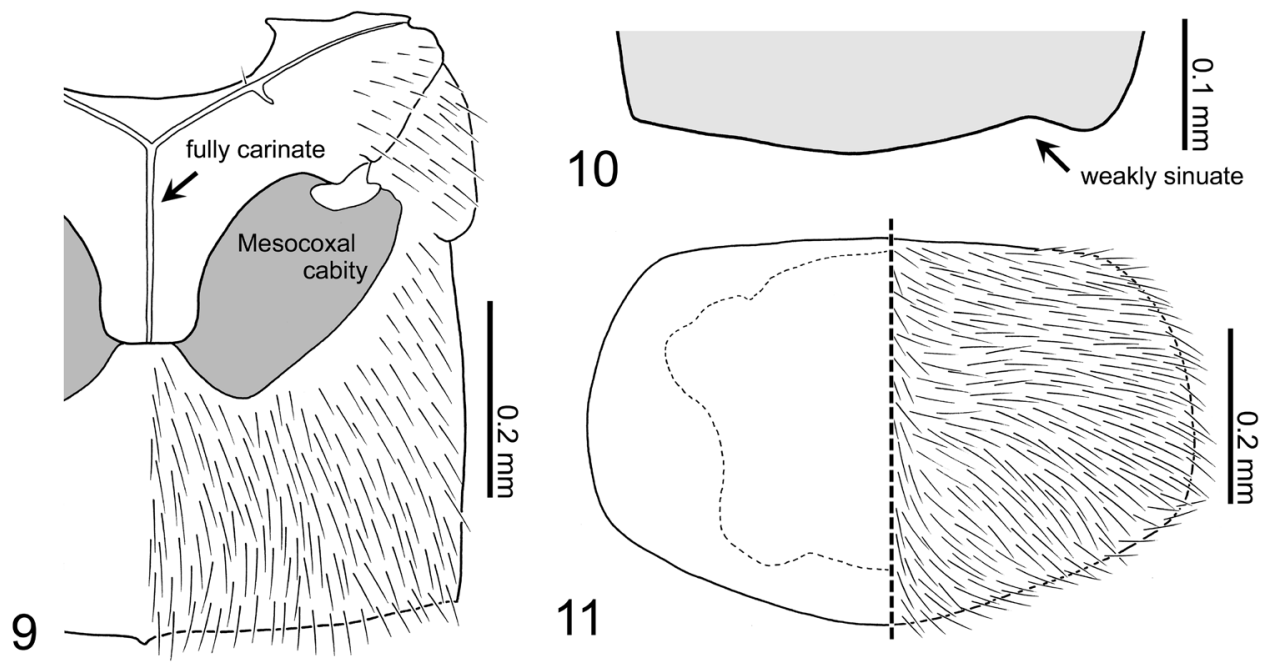

Figures 9-I I. Body parts of Aleochara (Tinotus) morion of male: 9 mesoventrite and metaventrite $\mathbf{I} \mathbf{0}$ right elytron, posterior margin II pronotum.

ered with setae densely, with approximately six macrosetae. Median lobe of aedeagus (Figs 16, 17): very slender in parameral view; apical lobe slender, weakly narrowing apically, and gently curved paramerally in lateral view; a conspicuous protuberance present at base of apical lobe (see arrow); a pair of simple sclerites, narrowly elongate, longer than half length of apical lobe; flagellum well developed, slightly shorter than median lobe, sharply curved near basal plate. Apical lobe of paramerite (Fig. 18): narrowly elongate, widest just above middle, with sharply pointed apex.

Female. Tergite VIII (Fig. 13): basal suture fully developed; posterior margin very weakly serrate, insignificantly emarginate medially; dorsal surface covered with setae rather sparsely, with five macrosetae. Sternite VIII (Fig. 15): basal suture fully developed; posterior margin rounded; ventral surface covered with setae densely, with approximately seven macrosetae. Spermatheca (Fig. 19): L-shaped; spermathecal head and neck fused together, forming a narrowly elongate capsule; attachment of spermathecal duct inconspicuous; basal part of spermathecal stem moderate in size, slightly longer than spermathecal neck, with four coils attached at base; each part of spermatheca entirely and very weakly sclerotized; inner wall of spermathecal head and neck, along border with head, finely and densely striate.

Distribution. This species has a wide range in distribution covering the entire Holarctic region, mainly Europe and North Africa (Schülke and Smetana 2015). The records in the Nearctic region are regarded as those species introduced from Europe (Klimaszewski et al. 2002). In Russia, the easternmost record reported is from West Siberia (Schülke and Smetana 2015). We provide new distributional records of A. morion as follows: new country record, Japan (Hokkaidô, Honshû); new regional record, the Russian Far East. 

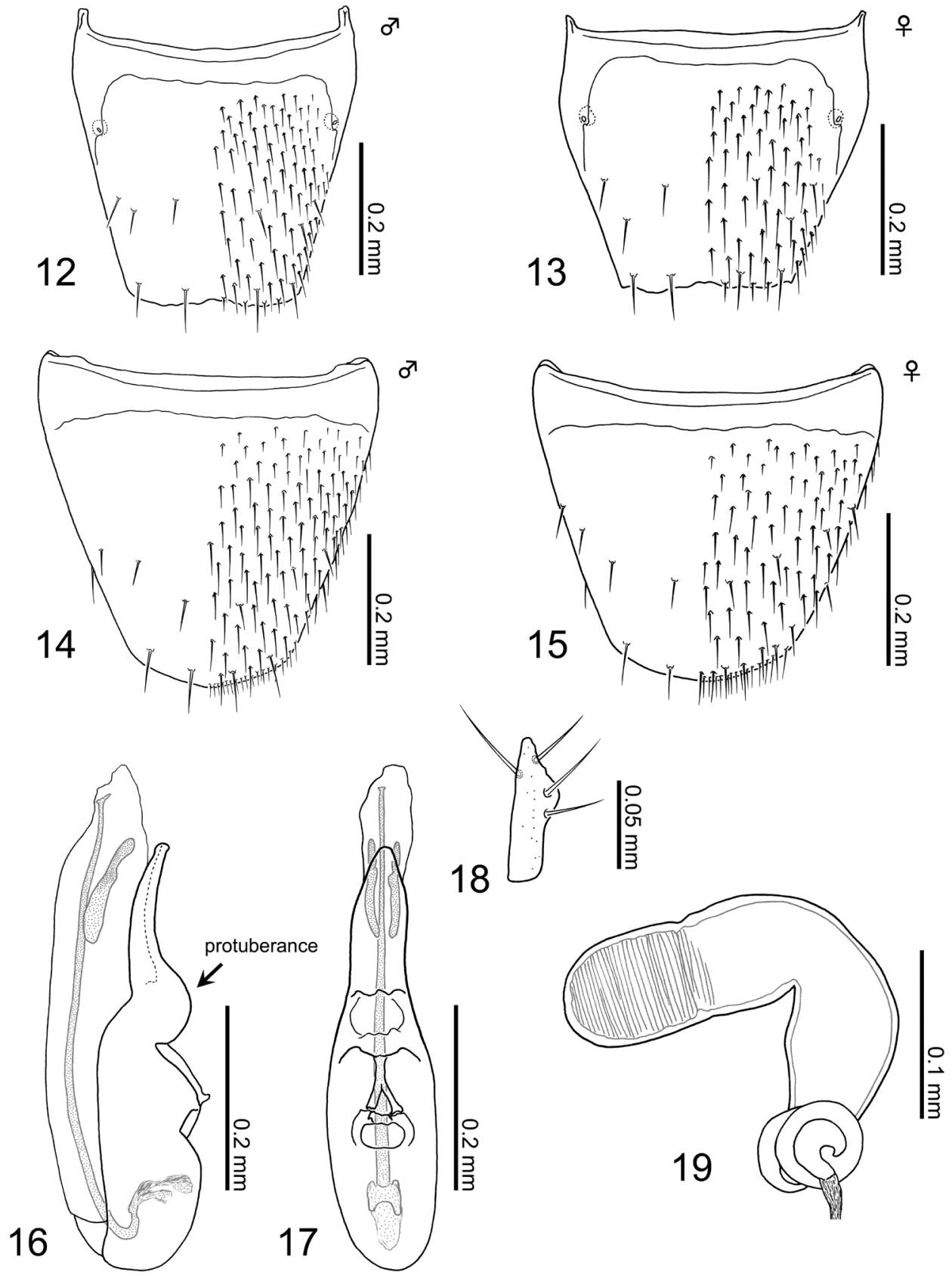

Figures I 2-19. Terminalia of Aleochara (Tinotus) morion: $\mathbf{2}$ tergite VIII of male I 3 tergite VIII of female $\mathbf{I}$ sternite VIII of male $\mathbf{I 5}$ sternite VIII of female $\mathbf{1 6}$ median lobe of male aedeagus, lateral view $\mathbf{I} \mathbf{7}$ ditto, parameral view $\mathbf{I} \mathbf{8}$ apical lobe of paramerite $\mathbf{1 9}$ female spermatheca. 
Bionomics. SY collected eight specimens from one Hokkaido brown bear (Ursus arctos) dung found on the roadside of a mixed needleleaf and broadleaf forest in Hokkaidô, Japan (Fig. 36). Aleochara morion has been found among various habitats, such as decaying organic matter, including fungi, compost, animal excrement, and carrion (Horion 1967). In addition, this species is found in moss, bark debris, straw, hay, and on sandy soil (Klimaszewski et al. 2002).

Host records. Three dipteran families are known as its host (Maus et al. 1998): Sepsidae, Drosophilidae, and Sarcophagidae.

Remarks. Whether this species is native to East Asia or just an introduction from Europe is unknown, although the records from North America suggest this species has been introduced (Klimaszewski et al. 2002). Recently, Pace (2013) recorded A. morion on the mainland of China.

\section{Aleochara (Tinotus) eoa nom. n.}

Figs 2, 20-26, 35

Tinotus japonicus Cameron, 1933: 217 (original description).

Tinotus japonicus: Smetana 2004: 362 (catalogue of Palearctic species of Aleocharinae);

Shibata et al. 2013: 106 (catalogue of Japanese species of Staphylinidae); Schülke and Smetana 2015: 505 (catalogue of Palearctic species of Aleocharinae).

Type locality. Kobe, Japan.

Type material examined. Tinotus japonicus: Lectotype (here designated): male, "SYN- / TYPE [BRL] // JAPAN / Kobe // J. E. A. Lewis // M. Cameron / Bequest. / B. M. 1955-147 // Tinotus / japonicus / TYPE Cam [HW] // Tinotus / japonicus / P. M. Hammond / det. 1973 / SYNTYPE // Lectotype / Tinotus japonicus / Cameron, 1933 / des. Maruyama, 2011" (abdominal segments VIII-X and aedeagus were dissected and mounted in Euparal by MM) (PL, $0.42 \mathrm{~mm}$; PW, $0.59 \mathrm{~mm}$; Hind tibial length, $0.40 \mathrm{~mm})(\mathrm{BMNH})$. Paralectoypes: 3 males, 1 female, same original labels as lectotype but without the label "Tinotus / japonicus / TYPE Cam [HW]" (abdominal segments VIII-X and spermatheca were dissected and glued on paper card together with body by $\mathrm{MM})(\mathrm{BMNH})$.

Additional material examined. JAPAN: Honshû: 1 female, Shigasaka-tôge Pass, Kanna-machi, Gunma-ken, 17-19.vi.2008, Flight Interception Trap, T. Watanabe leg. (KUM); 1 male, 2 females, Sugaya, Ranzan-machi, Saitama-ken, 10.iv.1994, K. Toyoda leg. (KUM). TAIWAN: Nantou: 1 male, 3 females, 5 spec., Songkang, 2000m, 14.iv.1986, M. Ôhara leg. (KUM).

Diagnosis. This species is distinguished from the other congeneric species of the subgenus by a following combination of character states: body reddish brown to dark brown (Fig. 2); median lobe of aedeagus of male with a coiled flagellum, and with two pairs of characteristic sclerites (Figs 24, 25); spermatheca with a curved spermathecal 

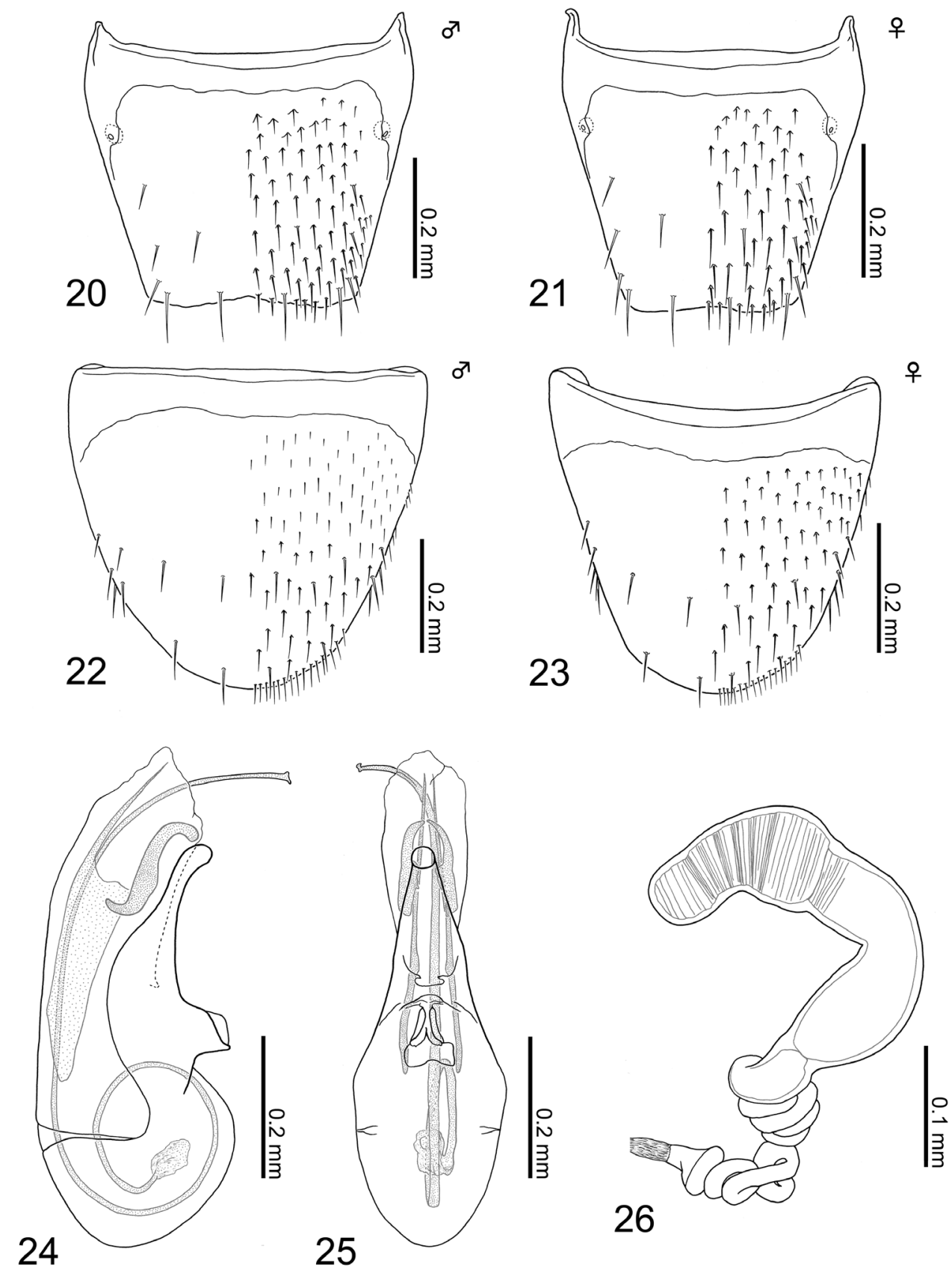

Figures 20-26. Terminalia of Aleochara (Tinotus) eoa: $\mathbf{2 0}$ tergite VIII of male $\mathbf{2 I}$ tergite VIII of female $\mathbf{2 2}$ sternite VIII of male $\mathbf{2 3}$ sternite VIII of female $\mathbf{2 4}$ median lobe of male aedeagus, lateral view $\mathbf{2 5}$ ditto, parameral view $\mathbf{2 6}$ female spermatheca. 
head, unequally serrated inner walls inside spermathecal head, and with multiple coils at base (Fig. 26). Aleochara eoa is the most similar externally to $A$. (T.) rougemontiana (Pace, 1999a), comb. n., from mainland China, differing from it additionally by having much less coiled spermatheca in the female (Pace 1999a: Fig. 183).

Redescription. Measurements (in mm, $\mathrm{n}=13)$ : $\mathrm{BL}=2.709(2.288-3.011) ; \mathrm{HL}=$ $0.427(0.358-0.511) ; \mathrm{HW}=0.439(0.380-0.486) ; \mathrm{PL}=0.466(0.368-0.565) ; \mathrm{PW}=$ $0.666(0.514-0.758) ; \mathrm{EW}=0.780(0.605-0.948)$.

Body (Fig. 2): fusiform, compact, and robust; dorsal surface somewhat strongly glossy and pubescent, covered with small and inconspicuous micro-reticulation.

Color (Fig. 2): usually uniformly dark reddish brown to dark brown; antennomeres I-IV much lighter, but segments V to XI darker with numerous minute whitish setae; mouthparts and legs light-yellowish brown to reddish brown; pubescence yellowish brown to brown.

Head (Fig. 2): subquadrate, as long as width $(\mathrm{HW} / \mathrm{HL}=1.03, \mathrm{n}=13)$, widest at base of eyes; setae on vertex rather dense, directed anteriomedially. Eyes: small, occupying approximately one third of head length, very slightly protruding laterally.

Antennae (Fig. 2): short, moderately shorter than head and pronotum combined; relatively thick, setaceous, becoming gradually and slightly broaden apically in segments IV to X, with segment V spherical and segments VI to X clearly transverse; segment XI symmetrical, obtusely pointed at apex; approximate relative length of segments from basal to apex: 21: 17: 14: 6: 7: 7: 7:7:7:7:18.

Pronotum (Fig. 2): strongly convex above dorsally, transverse (PW/PL $=1.43, \mathrm{n}=$ 13), moderately longer than sutural length of elytra, widest around below of basal half, basal margin weakly rounded; pubescence rather long, rather dense but thin, directed laterally and posterolaterally; micro-reticulation inconspicuous.

Elytra (Fig. 2): together, transverse, rather small, widest at middle; pubescence short, finely scattered densely, diverging posterolaterally in each elytron; dorsal surface moderately rough, shallowly impressed; posterolateral corner of each elytron moderately sinuate.

Abdomen (Fig. 2): first three visible tergites rather shallowly impressed transversely at base; dorsal and ventral surface covered with setae densely.

Male. Tergite VIII (Fig. 20): basal suture fully developed; posterior margin very weakly serrate, insignificantly emarginate medially; dorsal surface covered with setae rather sparsely, with six macrosetae. Sternite VIII (Fig. 21): basal suture fully developed; posterior margin rounded to only weakly produced; ventral surface covered with short setae sparsely, with approximately nine macrosetae. Median lobe of aedeagus (Figs 24 \& 25): ovular in lateral and limuloid in parameral view; apical lobe rather slender, gently curved paramerally, weakly narrowing apically in parameral but with weakly dilated apex in lateral view; without a protuberance at base of apical lobe; a pair of sclerites S-shaped, longer than half length of apical lobe; flagellum strongly developed, much longer than median lobe, coiled 1.5 times at base.

Female. Tergite VIII (Fig. 21): basal suture fully developed; posterior margin very weakly serrate or almost truncate; dorsal surface covered with setae rather sparsely, with 
six macrosetae. Sternite VIII (Fig. 23): basal suture fully developed; posterior margin rounded; ventral surface covered with setae rather sparsely, with approximately nine macrosetae. Spermatheca (Fig. 26): deformed M-shaped; spermathecal head curved at middle; attachment of spermathecal duct inconspicuous; basal part of spermathecal stem moderate in size, clearly longer than spermathecal neck, with approximately ten coils attached complicatedly at base; each part of spermatheca entirely and very moderately sclerotized; inner wall of spermathecal head and neck, along border with head, finely and densely striate irregularly.

Etymology. The replacement name is derived from "Eos" of the Greek mythology which is a Titaness and the goddess of the dawn because "Nippon" (= Japan, type locality) means a country of the dawn.

Distribution. Japan, Taiwan (new record).

Bionomics. One individual was caught with a flight interception trap (FIT).

Host records. No host record is available.

Remarks on type materials. Five syntypes were found. Among them, a male specimen (Fig. 35) labeled "Tinotus / japonicus / TYPE Cam [HW]" is designated as the lectotype herein.

Comments. Since the name Aleochara japonica was already preoccupied by Sharp (1874), a new replacement name, Aleochara (Tinotus) eoa nom. n., for Tinotus japonicus Cameron, 1933 [nec. Sharp, 1874: 8 (Aleochara)], is proposed herein. No record of this species exists since its original description.

\section{Aleochara (Tinotus) takashii sp. n.} http://zoobank.org/79D2ADA2-E87B-4F16-867C-904F9A438C20

Figs 3, 27-34

Type locality. Japan, Honshû: Takahachiyama, Fujinomiya City, Shizuoka Prefecture.

Type material. Holotype: male, "Takahachiyama / Fujinomiya-shi / Shizuoka, JAPAN / 17-24. VIII. 2010 / T. Watanabe leg. [printed] // Flight / Intercept. / Trap [printed] // Aleocharini / Gen. / sp. / det. T. Watanabe 2013 [yellow square paper card, printed]" (KUM).

Paratypes: 1 male, "Teppogino-atama / Nishitanzawa / Kanagawa, Japan / 5-12. VII. 2007 / T. Watanabe leg. // Flight / Intercept. / Trap" (KUM); 1 male, "Teppogino-atama / Nishitanzawa / Kanagawa, Japan / 5-12. VII. 2007 / T. Watanabe leg. // Flight / Intercept. / Trap // Aleochara / sp. / det. T. Watanabe 2007" (KUM); 1 male, "Teppogino-atama / Nishitanzawa / Kanagawa, Japan / 5-12. VII. 2007 / T. Watanabe leg. // Flight / Intercept. / Trap // Aleochara / sp. / det. T. Watanabe 2008” (KUM); 1 male, "Idenzawa / Nishitanzawa / Kanagawa, Japan / 31. V-6. VI. 2006 / T. Watanabe leg. // Aleochara / sp. / det. T. Watanabe 2007" (KUM); 2 spec., "Yanagisawa-toge / Enzan-shi / Yamanashi, Japan / 2-9. VIII. 2006 / T. Watanabe leg. // Flight / Intercept. / Trap // Aleochara / sp. / det. T. Watanabe 2007" (KUM); 1 female, "Yanagisawa-toge / Enzan-shi / Yamanashi, Japan / 9-15. VIII. 2006 / T. Watanabe leg. // Flight / Intercept. 

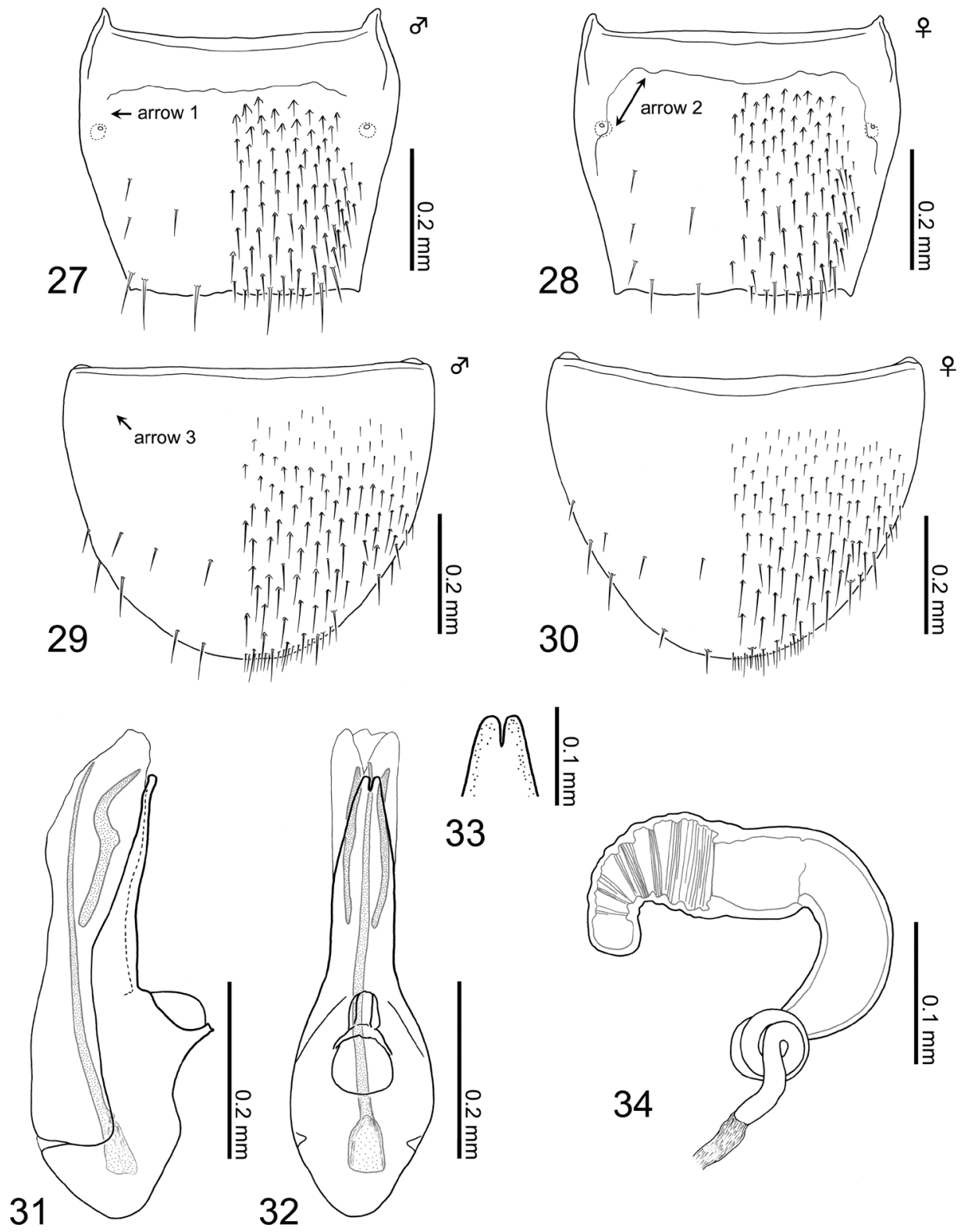

Figures 27-34. Terminalia of Aleochara (Tinotus) takashii: $\mathbf{2 7}$ tergite VIII of male $\mathbf{2 8}$ tergite VIII of female 29 sternite VIII of male $\mathbf{3 0}$ sternite VIII of female $\mathbf{3 I}$ median lobe of male aedeagus, lateral view $\mathbf{3 2}$ ditto, parameral view $\mathbf{3 3}$ ditto, apex of apical lobe, parameral view $\mathbf{3 4}$ female spermatheca.

/ Trap // Aleochara / sp. / det. T. Watanabe 2006" (PCTW); 2 females, "Karumizu-rindo / Narusawa-mura / Yamanashi, JAPAN / 30. VIII-14. IX. 2010 / T. Watanabe leg. // Aleochara / sp. / det. T. Watanabe 2012" (KUM); 1 female, "Karumizu-rindo / 1600 m, 
Narusawa / Yamanashi, JAPAN / 3-10. VIII. 2011 / T. Watanabe leg. // Flight / Intercept / Trap // Aleochara / sp. / det. T. Watanabe 2012" (KUM); 1 male, "Aokigahara, Fuji- / Kawaguchiko / Yamanashi, JAPAN 11-17. V. 2012 / T. Watanabe leg. // Flight / Intercept. / Trap / Aleochara / sp. / det. T. Watanabe 2013" (KUM); 1 male (head mounted on slide), 1 spec., "Fujisan 1-gome / Subashiri (1400 m) / Shizuoka, JAPAN / 20-26. V. 2011 / T. Watanabe leg. // Flight / Intercept. Trap // Aleochara / sp. / det. T. Watanabe 2012" (KUM); 1 male, 1 female, "Ohbuchi (alt. 950m) / Fuji-shi / Shizuoka, JAPAN / 13-18. V. 2010 / T. Watanabe leg. // Flight / Intercept. / Trap // Aleochara / sp. / det. T. Watanabe 2012" (KUM); 1 spec., "Ohbuchi (alt. 950m) / Fuji-shi / Shizuoka, JAPAN / 16-22. VII. 2010 / T. Watanabe leg. // Flight / Intercept. / Trap // Aleochara / sp. / det. T. Watanabe 2012" (KUM); 1 spec., "Ohbuchi (alt. 950m) / Fuji-shi / Shizuoka, JAPAN / 24. X. 2012 / T. Watanabe leg. // Aleocharinae” (KUM); 1 male, "Takahachiyama / Fujinomiya-shi / Shizuoka. JAPAN / 28. VIII. 2012 / T. Watanabe leg. // Aleocharinae" (KUM); 1 male, "Nishiusuzuka / Fujinomiya-shi / Shizuoka, JAPAN / 22-31. V. 2013 / T. Watanabe leg. // Flight / Intercept. / Trap // Aleochara / sp. / det. T. Watanabe 2013" (PCTW); 1 male, "Nishiusuzuka / Fujinomiya-shi / Shizuoka, JAPAN / 8-16. VII. 2010 / T. Watanabe leg. // Flight / Intercept. / Trap // Aleochara / sp. / det. T. Watanabe 2010" (PCTW); 1 male, 1 spec., "Nishiusuzuka / Fujinomiya-shi / Shizuoka, JAPAN / 16-22. VII. 2010 / T. Watanabe leg. // Flight / Intercept. / Trap // Aleochara / sp. / det. T. Watanabe 2011" (KUM); 1 spec., "Nishiusuzuka / Fujinomiyashi / Shizuoka, JAPAN / 17-24. VIII. 2010 / T. Watanabe leg. // Flight / Intercept. / Trap // Aleochara / sp. / det. T. Watanabe 2012" (KUM).

Diagnosis. This species can be easily distinguished from the other members of the subgenus by a following combination of characters: body entirely reddish brown (Fig. 3); abdominal segments III-V (first three visible terga) deeply impressed laterobasally; both tergite and sternite VIII with weakly developed basal sutures (Figs 27-30); median lobe of aedeagus with long apical lobe, notched deeply and medially at apex in ventral view (Fig. 33); spermatheca with a curved spermathecal head, unequally serrated inner walls inside spermathecal head, and with approximately three coils at base (Fig. 34). Aleochara takashii is the most similar to the North American species, $A$. (T.) imbricata (Casey, 1894), comb. n., of which shares including the similar configuration of male genitalia. From $A$. imbricata, it can be distinguished additionally by having much more developed sclerites inside the median lobe of the aedeagus and by overall shape of the spermatheca (Klimaszewski et al. 2002: 289: Figs 13-16, 31-33).

Description. Measurements (in $\mathrm{mm}, \mathrm{n}=23$ ): $\mathrm{BL}=3.156(2.637-3.669) ; \mathrm{HL}=$ 0.419 (0.361-0.483); $\mathrm{HW}=0.488(0.418-0.760) ; \mathrm{PL}=0.528(0.421-0.605) ; \mathrm{PW}=$ 0.756 (0.599-0.866); EW $=0.880(0.693-1.019)$.

Body (Fig. 3): fusiform, compact, and robust; dorsal surface moderately glossy and pubescent, covered with small and inconspicuous micro-reticulation.

Color (Fig. 3): usually uniformly dark reddish brown to dark brown; elytra lighter; antennomeres I-IV lighter, but segments V to XI darker with numerous minute whitish setae; mouthparts and legs yellowish brown to dark reddish brown; apices of tergites III-V pale reddish brown transversely; pubescence yellowish brown to brown. 

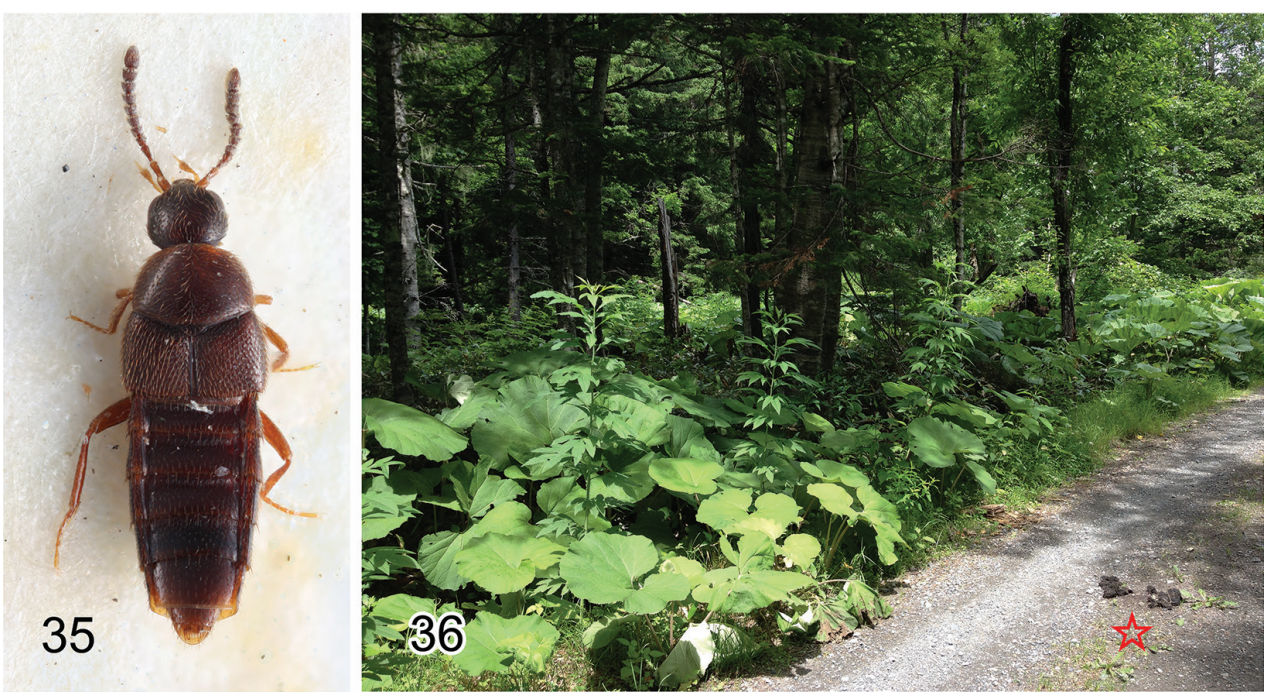

Figures 35-36. Type material and habitat of Aleochara (Tinotus): 35 lectotype of Tinotus japonicus (= A. eoa) 36 Habitat of $A$. (T.) morion at Shihoro (Hokkaidô, Japan), red star indicating bear dung where eight specimens were collected.

Head (Fig. 3): subquadrate, slightly transverse $(\mathrm{HW} / \mathrm{HL}=1.17, \mathrm{n}=23)$, widest just behind base of eyes; setae on vertex rather dense, directed anteriomedially. Eyes: small, occupying approximately one third of head length, very slightly protruding laterally.

Antennae (Fig. 3): short, moderately shorter than head and pronotum combined; relatively thick, setaceous, becoming gradually and moderately broaden apically in segments $\mathrm{V}$ to $\mathrm{X}$, with segment $\mathrm{V}$ elongate and segments VI to X clearly transverse; segment XI symmetrical, obtusely pointed at apex; approximate relative length of segments from basal to apex: 23: 16: 17: 10: 9: 9: 9: 9: 9: 9: 22 .

Pronotum (Fig. 3): strongly convex above dorsally, transverse (PW/PL $=1.43, \mathrm{n}$ = 23), moderately longer than sutural length of elytra, widest around below of basal half, basal margin weakly rounded; pubescence in moderate length but thin, directed laterally and posterolaterally; micro-reticulation inconspicuous.

Elytra (Fig. 3): together, transverse, rather small, widest at middle; pubescence short, finely scattered densely, diverging posterolaterally in each elytron; dorsal surface moderately rough, shallowly impressed; posterolateral corner of each elytron moderately sinuate.

Abdomen (Fig. 3): first three visible tergites deeply impressed transversely at base; dorsal and ventral surface covered with setae rather sparsely.

Male. Tergite VIII (Fig. 27): basal suture not fully developed, suture partially disappeared laterally (Fig. 27: arrow 1); posterior margin very weakly serrate, insignificantly emarginate medially or truncate; dorsal surface covered with setae rather densely, with six macrosetae. Sternite VIII (Fig. 29): basal suture completely lost (Fig. 29: arrow 3); posterior margin rounded; ventral surface covered with short setae dense- 
ly, with approximately eight macrosetae. Median lobe of aedeagus (Figs 31-33): narrowly elongate in lateral, and limuloid narrowly in parameral view; apical lobe slender and long, as long as basal capsule, moderately narrowing apically in lateral view, with deeply notched apex medially in parameral view (Fig. 33); without a protuberance at base of apical lobe; a pair of sclerites curved just above middle, long, approximately $2 / 3$ length of apical lobe; flagellum developed, shorter than median lobe, without any coils at base.

Female. Tergite VIII (Fig. 28): basal suture not fully developed, suture partially disappeared laterally like male (see Fig. 27: arrow 1) or at most weakly developed (Fig. 28: arrow 2); posterior margin very weakly serrate or almost truncate; dorsal surface covered with setae densely, with six macrosetae. Sternite VIII (Fig. 30): basal suture completely lost like male (see Fig. 29: arrow 3); posterior margin rounded; ventral surface covered with setae densely, with approximately eight macrosetae. Spermatheca (Fig. 34): curved semi-circularly in lateral view; spermathecal head curved at middle; attachment of spermathecal duct inconspicuous; basal part of spermathecal stem moderate in size, clearly longer than spermathecal neck, with approximately three coils; each part of spermatheca entirely and very moderately sclerotized; inner wall of spermathecal head, coarsely striate irregularly.

Etymology. The species name is dedicated to its collector, Mr. Takashi Watanabe (Kanagawa, Japan).

Distribution. Only known from central Honshû, Japan (Kanagawa, Yamanashi, and Shizuoka Prefectures).

Bionomics. Most specimens were caught with flight interception traps (FIT).

Host records. No host record is available.

Remarks. This new species is distinct among the species of Tinotus. In particular, reduced or non-developed basal sutures on tergite and sternite VIII of both sexes are notable character states (Figs 27-30). Furthermore, the apical lobe of the median lobe of male aedeagus, [i.e., deeply notched medially at apex in parameral view (Fig. 33)], is also a remarkable character state even among the subfamily. Since other morphological characters correspond fully to that of the subgenus Tinotus, we assign this species to Tinotus without hesitation.

Key to species of the subgenus Tinotus (genus Aleochara) from Japan, Taiwan, and the Russian Far East

$1 \quad$ Body black to blackish brown including pronotum and elytra (Fig. 1); median lobe of aedeagus of male with a basal protuberance in lateral view (Fig. 16); spermatheca coiled four times basally, with oblong and simple spermathecal head (Fig. 19) Aleochara (Tinotus) morion Gravenhorst, 1802, comb. $\mathrm{n}$.

- $\quad$ Body dark brown to reddish brown (Figs 2, 3); median lobe of aedeagus of male without a basal protuberance in lateral view (Figs 24, 31); spermatheca with curved and deformed spermathecal head (Figs 26, 34) 
2 Abdominal segments III-V (first three visible terga terga) deeply impressed laterobasally; tergite and sternite VIII with reduced basal sutures (Figs 27-30); median lobe of male aedeagus with short flagellum (Figs 31-32); spermatheca with approximately three coils at base (Fig. 34) A. (T.) takashii sp. n.

- $\quad$ Abdominal segments III-V (first three visible terga terga) rather shallowly impressed laterobasally; tergite and sternite VIII with complete basal sutures (Figs 20-23); median lobe of male aedeagus with long and coiled flagellum (Figs 24, 25); spermatheca with complex multiple coils at base (Fig. 26) A. (T.) eoa nom. n.

\section{Discussion}

We recognize three Tinotus species from Japan. This species count is clearly lower than those for mainland China (6 spp.: Pace 2013a; Schülke and Smetana 2015) and the United States (6 spp.: Klimaszewski et al. 2002; Gusarov 2003). In contrast, it surpasses the counts of adjacent countries, e.g., South and North Korea (0 sp.: Schülke and Smetana 2015) and Russia, including the Far East (1 sp.; Schülke and Smetana 2015; present study). Surprisingly, all of the continental European countries has no, or at most, only one Tinotus species (A. morion; Schülke and Smetana 2015). Within central Honshû, Japan, we found all of the three species. Therefore, Japan, especially central part of the country, is considered to possess a relatively high species diversity of Tinotus.

Only one species has been confirmed in Taiwan and the Russian Far East, respectively, which may reflect potentially low species diversity in these regions or merely insufficient accumulation of materials. Since taxonomic studies and records of Tinotus in East Asia, including these two regions, are still lacking, further discussions are avoided here. The finding of $A$. eoa in Taiwan implies a wide distributional range of this species, and it may be discovered on mainland China.

\section{Acknowledgements}

We are grateful to Alfred F. Newton (FMNH) for checking our checklist of Tinotus and giving us meaningful suggestions. Our thanks are extended to all the colleagues indicated in the material section for offering us the valuable specimens for the present study, especially Roger G. Booth (BMNH), Alfred F. Newton, Margaret K. Thayer, and Rebekah S. Baquiran (FMNH) for allowing us to examine the specimens during our stay in their institutions. Thanks are also due to Jan Klimaszewski (Laurentian Forestry Centre, Quebec) and Roberto Pace (Verona) for their valuable comments on our new arrangements of Tinotus. SY thanks Toshiya Hirowatari (Kyushu University, Fukuoka, Japan) for reading of the early version of the manuscript. Finally, we thank Volker Assing and Edilson Caron for improving our manuscript. This study was partially supported by the Grant-in-Aid for JSPS Fellows (14J02669) to SY from the Japan Society for the Promotion of Science. MM thanks Tetsukazu Yahara (Kyushu 
University) for arranging MM's research trips to London and Chicago. This is a contribution from the Entomological Laboratory, Faculty of Agriculture, Kyushu University, Fukuoka, Japan (Ser. 7, No. 23).

\section{References}

Ashe JS (2000) Aleocharinae. In: Arnett RH, Thomas MC (Eds) American Beetles (Vol. 1) - Archostemata, Myxophaga, Adephaga, Polyphaga: Staphyliniformia. CRC Press, Boca Raton, $272-418$.

Bernhauer M (1906) Neue Aleocharinen aus Nordamerika (II Teil). Deutsche Entomologische Zeitschrift 1906: 337-348.

Bernhauer M (1915) Zur Staphyliniden-Fauna des tropischen Afrika. VII. Annales HistoricoNaturales Musei Nationalis Hungarici 13: 95-189.

Bernhauer M (1934a) Neue Staphyliniden aus Argentinien (Coleoptera). Beitrag zur Südamerikanischen Fauna (XXXIV). Revista de Entomologia (Rio de Janeiro) 4: 501-517.

Bernhauer M (1934b) Siebenter Beitrag zur Staphylinidenfauna Chinas. Entomologisches Nachrichtenblatt (Troppau) 8: 1-20.

Bernhauer M, Scheerpeltz O (1926) Staphylinidae VI (Pars 82). In: Junk W, Schenkling S (Eds) Coleopterorum Catalogus (Vol. 5) Staphylinidae. W Junk, Berlin, 499-988.

Blackwelder RE (1952) The generic names of the beetle family Staphylinidae, with an essay on genotypy. United States National Museum Bulletin 200: 1-483.

Cameron M (1920) New species of Staphylinidae from Singapore, part III. Transactions of the Entomological Society of London 1920: 212-284. doi: 10.1111/j.1365-2311.1920.tb00214.x

Cameron M (1933) New species of Staphylinidae (Col.) from Japan. Entomologist's Monthly Magazine 69: 208-219.

Cameron M (1939) Coleoptera, Staphylinidae (Vol. IV. Parts I \& II). In: Sewell RBS (Ed.) The fauna of British India, including Ceylon and Burma. Taylor \& Francis, London, 690 pp.

Cameron M [1945 (1944)] New species of South African Staphylinidae (Col.). Annals and Magazine of Natural History (ser. 11) 11: 705-730.

Cameron M (1950a) New species of Staphylinidae (Col.) from the Malay Peninsula. The Annals and Magazine of Natural History (ser. 12) 3: 1-40, 89-131.

Cameron M (1950b) Staphylinidae (Coleoptera Polyphaga). Explorations du Parc National Albert 59: 1-85.

Casey TL (1894) Coleopterological notices. V. Annals of the New York Academy of Sciences 7: 281-606. doi: 10.1111/j.1749-6632.1893.tb55411.x

Casey TL (1906) Observations on the staphylinid groups Aleocharinae and Xantholinini chiefly of America. Transactions of the Academy of Science of St. Louis 16: 125-435.

Casey TL (1911) New American species of Aleocharinae and Myllaeninae. Memoirs on the Coleoptera 2: 1-245.

Eichelbaum F (1912) Die von Herrn Dr. Christoph Schröder in den Parehbergen und auf dem Kilimandjaro im Januar 1906 gesammelten Staphylinidae (darunter zwei neue Philonthusarten). Berliner Entomologische Zeitschrift 56: 173-176. 
Erichson WF (1839) Genera et Species Staphylinorum Insectorum Coleopterorum Familiae. Part 1. FH Morin, Berlin, 400 pp.

Fairmaire L [1858 (1857)] Miscellanea Entomologica. Deuxièm e partie. Annales de la Sociètè Entomologique de France (3) 5: 725-745.

Fauvel A (1900) Staphylinides paléarctiques nouveaux. Revue d'Entomologie 19: 218-253.

Fauvel A (1904) Staphylinides de l'Hindoustan et de la Birmanie. Revue d'Entomologie 23(4/5): 43-70.

Fenyes A (1914) H. Sauter's Formosa-Ausbeute. Aleocharinae. Archiv für Naturgeschichte (A) 80(2): 45-55.

Fenyes A (1918-1921) Coleoptera (Fam. Staphylinidae, subfam. Aleocharinae). In: Wytsman P (Ed.) Genera Insectorum, Fasc. 173a-c. M. Nijhoff, The Hague and L. Desmet-Verteneuil, Brussels, 453 pp.

Fournet S, Stapel JO, Kacem N, Nenon JP, Brunel E (2000) Life history comparison between two competitive Aleochara species in the cabbage root fly, Delia radicum: implications for their use in biological control. Entomologia Experimentalis et Applicata 96: 205-211. doi: 10.1046/j.1570-7458.2000.00698.x

Gouix N, Klimaszewski J (2007) Catalogue of aleocharine rove beetles of Canada and Alaska (Coleoptera, Staphylinidae, Aleocharinae). Pensoft Publishers, Sofia and Moscow, 165 pp.

Gusarov VI (2003) Revision of some types of North American aleocharines (Coleoptera: Staphylinidae: Aleocharinae), with synonymic notes. Zootaxa 353: 1-134.

Gravenhorst JLC (1802) Coleoptera Microptera Brunsvicensia nec non exoticorum quotquot exstant in collectionibus entomologorum Brunsvicensium in genera familias et species distribuit. Carolus Reichard, Brunsuigae, 206 pp. doi: 10.5962/bhl.title.9568

Gravenhorst JLC (1806) Monographia Coleopterorum Micropterorum. Henricus Dieterich, Gottingae, $236 \mathrm{pp}$.

Hanley RS (2002) A new species of Mexican Tinotus from the refuse piles of Atta ants, including an annotated world catalog of Tinotus (Coleoptera: Staphylinidae: Aleocharinae: Aleocharini). Coleopterists Bulletin 56(4): 453-471. doi: 10.1649/0010-065X(2002)056 [0453:ANSOMT]2.0.CO;2

Horion A (1967) Faunistik der mitteleuropäischen Käfer. Staphylinidae. 3. Habrocerinae bis Aleocharinae (Ohne Subtribus Athetae). PCW Schmidt, Überlingen-Bodensee 11: 1-419.

Keys JH (1907) Exaleochara: a genus of Coleoptera new to science. Entomologist's Monthly Magazine 43: 102.

Klimaszewski J (1984) A revision of the genus Aleochara Gravenhorst of America north of Mexico. Memoirs of the Entomological Society of Canada 129: 1-129. doi: 10.4039/entm116129fv Klimaszewski J, Brunke A, Assing V, Langor DW, Newton AF, Bourdon C, Pelletier G, Webster RP, Herman L, Perdereau L, Davies A, Smetana A, Chandler DS, Majka C, Scudder GGE (2013) Synopsis of adventive species of Coleoptera (Insecta) recorded from Canada. Part 2: Staphylinidae. Pensoft Publishers, Sofia and Moscow, 360 pp.

Klimaszewski J, Jansen RE (1993) Systematics, biology and distribution of Aleochara Gravenhorst from Southern Africa. Part 1: subgenus Xenochara Mulsant \& Rey (Coleoptera: Staphylinidae). Annals of the Transvaal Museum 36(7): 53-107. 
Klimaszewski J, Pelletier G, Sweeney J (2002) Genus Tinotus (Coleoptera: Staphylinidae, Aleocharinae) from America north of Mexico: review of the types, distribution records, and key to species. Canadian Entomologist 134(3): 281-298. doi: 10.4039/Ent134281-3

Kraatz G (1859) Die Staphylinen-Fauna von Ostindien, insbesondere der Insel Ceylan. Archiv für Naturgeschichte 25: 1-196. doi: 10.5962/bhl.title.66002

Likovský Z (1984) Über die nomenklatur der Aleocharinen (Coleoptera, Staphylinidae). Annotationes Zoologicae et Botanicae 160: 1-8.

Lohse GA (1974) Die Käfer Mitteleuropas. Bd. 5. Staphylinidae II (Hypocyphtinae und Aleocharinae) Pselaphidae. Goeke \& Evers, Krefeld, 381 pp.

Mannerheim CG (1830) Précis d'un nouvel arrangement de la famillie des brachélytres de l'ordre des insectes coléoptères. St. Petersbourg, $87 \mathrm{pp}$.

Maruyama M (2006) Revision of the Palearctic species of the myrmecophilous genus Pella: Coleoptera, Staphylinidae, Aleocharinae. National Science Museum Monographs 32: 1-207.

Maus C (1999) Four new species of the genus Aleochara Gravenhorst, 1802, subgenus Coprochara Mulsant et Rey, 1874. Beiträge zur Entomologie 49: 357-367.

Maus C, Mittmann B, Peschke K (1998) Host records of parasitoid Aleochara Gravenhorst species (Coleoptera, Staphylinidae) attacking puparia of cyclorrhapheous Diptera. Deutsche Entomologische Zeitschrift 45(2): 231-254. doi: 10.1002/mmnd.19980450209

Maus CH, Peschke K, Dobler S (2001) Phylogeny of the genus Aleochara inferred from mitochondrial cytochrome oxidase sequences (Coleoptera: Staphylinidae). Molecular Phylogenetics and Evolution 18(2): 202-216. doi: 10.1006/mpev.2000.0874

Motschulsky V de (1858) Énumeration des nouvelles espèces de coléoptères rapports de ses voyages. Bulletin de la Société Impériale des Naturalistes de Moscou 31(3): 204-264.

Mulsant E, Rey C (1874) Histoire naturelle des coléoptères de France. Brévipennes. Aléochariens. (Suite). Aléocharaires. Deyrolle, Paris, 565 pp.

Notman H (1920) Staphylinidae from Florida in the collection of the American Museum of Natural History, with descriptions of new genera and species. Bulletin of the American Museum of Natural History 42: 693-732.

Notman H (1921) Some new genera and species of Coleoptera collected at Westfield, Chautauqua Co., N. Y. Journal of the New York Entomological Society 29: 145-160.

Osswald J, Bachmann L, Gusarov VI (2013) Molecular phylogeny of the beetle tribe Oxypodini (Coleoptera: Staphylinidae: Aleocharinae). Systematic Entomology 38(3): 507-522. doi: $10.1111 /$ syen. 12011

Pace R (1984) Aleocharinae dell'Himalya LI. Contributo alla conoscenza delle Aleocharinae (Coleoptera, Staphylinidae). Annales de la Société Entomologique de France 20: 309-339.

Pace R (1986) Aleocharinae dell'Africa Orientale (Coleoptera, Staphylinidae). Annales HistoricoNaturales Musei Nationalis Hungarici 78: 83-143.

Pace R [1992 (1989)] Aleocharinae della Thailandia (Coleoptera, Staphylinidae) (XCV contributo alla conoscenza delle Aleocharinae). Bollettino del Museo Civico di Storia Naturale di Verona 16: 227-268.

Pace R (1990) Aleocharinae neotropiche del Museo Ungherese di Storia Naturale (Coleoptera, Staphylinidae). Annales Historico-Naturales Musei Nationalis Hungarici 81: 53-107. 
Pace R (1991) La sottofamiglia Aleocharinae della nuova Caledonia (Coleoptera Staphylinidae) (1088 contributo alla conoscenza delle Aleocharinae). Memorie della Società Entomologica Italiana 70: 79-170.

Pace R [1993 (1990)] Aleocharinae della Cina (Coleoptera, Staphylinidae). Bollettino del Museo Civico di Storia Naturale di Verona 17: 69-125.

Pace R (1997) Aleocharinae della Colombia e dell'Ecuador: Parte III (conclusione) (Coleoptera, Staphylinidae). Revue Suisse de Zoologie 104: 17-48. doi: 10.5962/bhl.part.79988

Pace R (1999a) Aleocharinae della Cina: Parte V (conclusione) (Coleoptera, Staphylinidae). Revue Suisse de Zoologie 106: 107-164. doi: 10.5962/bhl.part.80073

Pace R [1999b (1998)] Aleocharinae della Namibia raccolte dalla spedizione entomologica "Namibia 1992" del Museo di Storia Naturale di Berlino (Coleoptera: Staphylinidae). Memorie della Societa Entomologica Italiana 77: 161-212.

Pace R (2000) Aleocharinae di Papua-Nuova Guinea (Coleoptera: Staphylinidae). (156 Contributo alla conoscenza delle Aleocharinae). Bulletin de l'Institut Royale des Sciences Naturelles de Belgique, Entomologie 70: 109-163.

Pace R (2001) Aleocharinae di Hanoi (Vietnam) (Coleoptera, Staphylinidae). Bulletin de l'Institut Royal des Sciences Naturelles de Belgique Entomologie (Belgium) 71: 135-144. Pace R (2008a) New records of Aleocharinae from Ecuador and Peru, with the description of new species, new subgenera and new genera (Coleoptera, Staphylinidae). Biodiversity of South America I. Memoirs on Biodiversity, World Biodiversity Association onlus, Verona 1: 225-398.

Pace R (2008b) Le specie di Thamiaraeini, Oxypodini, Hoplandriini e Aleocharini del Borneo (Coleoptera, Staphylinidae). Revue Suisse de Zoologie 115(1): 157-183. doi: 10.5962/ bhl.part. 80424

Pace R (2011) New and additional records, new genera and new species of Aleocharinae from Venezuela, Ecuador and Peru (Coleoptera, Staphylinidae). Bollettino del Museo Civico di Storia Naturale di Verona, Botanica Zoologia 35: 43-70.

Pace R (2013a) Biodiversita delle Aleocharinae della Cina: Hoplandriini, Aleocharini e Sinanarchusini (Coleoptera, Staphylinidae). Beiträge zur Entomologie 63(1): 5-24.

Pace R (2013b) Nuovo contributo alla conoscenza delle Aleocharinae della Regione Orientale (Insecta: Coleoptera: Staphylinidae). Vernate 32: 371-381.

Redtenbacher L (1849) Fauna Austriaca. Die Käfer. Nach der analytischen Methode bearbeitet. Carl Gerold, Wien, 883 pp.

Sawada K (1972) Methodological research in the taxonomy of Aleocharinae. Contribution from the Biological Laboratory Kyoto University 24(1): 31-59.

Sawada K (1987) Atheta and its allies of Southeast Asia (Coleoptera: Staphylinidae). V. Singaporean species described in Cameron, 1920. Contributions from the Biological Laboratory, Kyoto University 27(2): 137-150.

Scheerpeltz O (1929) Staphyliniden aus Ostasien. Neue Beiträge zur Systematischen Insektenkunde 4: 114-128, 129-142.

Scheerpeltz O (1936) Die von Prof. Dr. H. Eidmann gelegentlich seiner im Jahre 1933 nach Brasilien unternommenen Studienreise aufgesammelten Staphyliniden. I. Die in den Nestern von Atta sexdens L. aufgefundenen Staphyliniden, nebst einigen Bemerkungen über die Gat- 
tung Scariphaeus Er. Archiv für Naturgeschichte. Zeitschrift für Systematische Zoologie 5(4): 483-540.

Schülke M, Smetana A (2015) Staphylinidae. In: Löbl I, Löbl D (Eds) Catalogue of Palaearctic Coleoptera, revised and updated edition. Vol. 2. Hydrophiloidea, Staphylinoidea. Brill, Leiden, 304-1134.

Seevers CH (1978) A generic and tribal revision of the North American Aleocharinae (Coleoptera: Staphylinidae). Fieldiana Zoology 71: 1-289.

Sharp DS (1874) The Staphylinidae of Japan. The Transactions of the Entomological Society of London 1874: 1-103. doi: 10.1111/j.1365-2311.1874.tb00159.x

Sharp DS (1883) Fam. Staphylinidae (in part). Biologia Centrali-Americana. Insecta, Coleoptera. Vol. 1, Part 2. Taylor \& Francis, London, 145-312.

Shibata Y, Maruyama M, Hoshina H, Kishimoto T, Naomi S-I, Nomura S, Puthz V, Shimada T, Watanabe Y, Yamamoto S (2013) Catalogue of Japanese Staphylinidae (Insecta: Coleoptera). Bulletin of the Kyushu University Museum 11: 69-218.

Smetana A (2004) Aleocharinae. In: Löbl I, Smetana A (Eds) Catalogue of Palaearctic Coleoptera. Vol. 2. Hydrophiloidea, Histeroidea, Staphylinoidea. Apollo Books, Stenstrup, Denmark, 353-494.

Stephens JF (1832) Illustrations of British entomology, or a synopsis of indigenous insects, containing their generic and specifi c distinctions, with an account of their metamorphoses, times of appearance, localities, food, and economy, as far as practicable. Mandibulata, Vol. 5. Baldwin \& Cradock, London, 1-240.

Wasmann E (1900) Neue Dorylinengäste aus dem neotropischen und dem äthiopischen Faunengebiet. 114. Beitrag zur Kenntniss der Myrmekophilen und Termitophilen. Zoologische Jahrbücher 14: 215-289.

Welch RC (1997) The British species of the genus Aleochara Gravenhorst (Staphylinidae). Coleopterist 6(1): 1-45.

White EB, Legner EF (1966) Notes on the life history of Aleochara taeniata, a staphylinid parasite of the house fly, Musca domestica. Annals of the Entomological Society of America 59(3): 573-577. doi: 10.1093/aesa/59.3.573

Yamamoto S, Maruyama M (2012) Revision of the seashore-dwelling subgenera Emplenota Casey and Triochara Bernhauer (Coleoptera: Staphylinidae: genus Aleochara) from Japan. Zootaxa 3517: 1-52.

Yamamoto S, Maruyama M (2013) Revision of the subgenus Coprochara Mulsant \& Rey of the genus Aleochara Gravenhorst from Japan (Coleoptera: Staphylinidae: Aleocharinae). Zootaxa 3641(3): 201-222. doi: 10.11646/zootaxa.3641.3.1

\section{Appendix}

Checklist of the world species of the subgenus Tinotus of the genus Aleochara. Forty species are recognized in total. See annotated checklist of world species of Tinotus by Hanley (2002) for further details. 


\section{Genus Aleochara Gravenhorst, 1802}

\section{Subgenus Tinotus Sharp, 1883: 170, stat. n.}

1. acerba (Casey, 1911: 15), comb. n. (Acrimea). Distribution: Canada, USA. = resecta (Casey, 1911: 14) (Acrimea).

2. andensis (Pace, 2008a: 365), comb. n. (Tinotus). Distribution: Ecuador.

3. arawakorum (Pace, 1990: 74), comb. n. (Tinotus). Distribution: Brazil (São Paulo). 4. boreoindica nom. n. [for indica (Cameron, 1939: 557) (Tinotus), nec. Fauvel, 1904:

66 (Maseochara), nec. Cameron, 1939: 635 (Aleochara)]. Distribution: India, China (Hubei, Shaanxi).

Etymology. Meaning northern India where the type locality is located.

5. caelatimas (Pace, 2008b: 177), comb. n. (Tinotus). Distribution: Malaysia (Sabah).

6. carnivora (Cameron, 1920: 270), comb. n. (Paratheta), nec. Gravenhorst, 1806:

171 (Aleochara). Distribution: Singapore.

7. caviceps (Casey, 1894: 316), comb. n. (Tinotus). Distribution: Canada, USA.

= parata (Casey, 1911: 64) (Tinotus).

8. cavicollis (Sharp, 1883: 170), comb. n. (Tinotus). Distribution: USA (FL), Guatemala, Nicaragua, Brazil, Paraguay, Argentina, Cuba.

9. clavicornuta nom. n. [for clavicornis (Cameron, 1945: 729) (Tinotus), nec. L. Redtenbacher, 1849: 822 (Aleochara)]. Distribution: South Africa.

Etymology. Small change of the older specific epithet for this species, clavicornis, meaning clavate antenna.

10. densula Wasmann, 1900: 240, comb. n. Distribution: South Africa.

11. eoa nom. n. [for japonica (Cameron, 1933: 217) (Tinotus), nec. Sharp, 1874: 8 (Aleochara)]. Distribution: Japan, Taiwan (new record).

Etymology. See, the redescription section above.

12. flavescens (Sharp, 1883: 171), comb. n. (Tinotus). Distribution: Mexico, Guatemala.

13. frontalis (Pace, 1997: 45), comb. n. (Tinotus), nec. Stephens, 1832: 111 (Aleochara). Distribution: Colombia.

14. globicollis (Bernhauer, 1934b: 19), comb. n. (Tinotus). Distribution: China (Sichuan), Philippines.

15. imbricata (Casey, 1894: 317), comb. n. (Tinotus). Distribution: USA.

= texana (Casey, 1911: 67) (Tinotus), nec. Casey, 1906: 137 (Aleochara).

= coelebs (Casey, 1911: 68) (Tinotus).

= fusina (Casey, 1911: 68) (Tinotus).

= pectinella (Casey, 1911: 69) (Tinotus).

= ampla (Notman, 1920: 723) (Tinotus).

= brunnipes (Notman, 1920:724) (Tinotus), nec. Stephens, 1832: 133 (Aleochara).

16. janklimaszewskii nom. n. [for klimaszewskii (Pace, 2008a: 365) (Tinotus), nec. Maus, 1999: 358 (Aleochara)]. Distribution: Ecuador.

Etymology. Dedicated to Dr. Jan Klimaszewski, as the older specific epithet for this species. 
17. kashmirica (Cameron, 1939: 559), comb. n. (Tinotus). Distribution: India (Kashmir, Himachal Pradesh).

18. malaya nom. n. [for antennalis (Cameron, 1950a: 128) (Tinotus), nec. Fenyes 1914: 54 (Aleochara)]. Distribution: Malaysia (Malay Peninsula).

Etymology. An old name of Peninsular Malaysia where the type locality is located.

19. morion Gravenhorst, 1802: 97, comb. n. Distribution: Holarctic region (native to Palaearctic region).

= exigua Mannerheim, 1930: 68 (Aleochara).

20. namibiensis (Pace, 1999b: 207), comb. n. (Tinotus). Distribution: Namibia.

21. natalensis (Pace, 1986: 107), comb. n. (Tinotus). Distribution: Kenya, Zimbabwe, South Africa.

22. ndogo nom. n. [for minuta (Bernhauer, 1915b: 158) (Tinotus), nec. Casey, 1906: 161 (Baryodma)]. Distribution: Zaire, Tanzania, Kenya, South Africa. = suffusa (Cameron, 1950b: 76) (Tinotus), nec. Casey, 1906: 162 (Baryodma).

23. neocaledonica (Pace, 1991: 165), comb. n. (Tinotus). Distribution: New Caledonia. Etymology. Swahili adjective ndogo meaning small in referring to the minute body of this species.

24. nepalensis (Pace, 1984: 338), comb. n. (Tinotus). Distribution: Nepal.

25. olivosensis nom. n. [for densissima (Bernhauer, 1934a: 512) (Tinotus), nec. Bernhauer, 1906: 345 (Aleochara)]. Distribution: Brazil (Rio de Janeiro), Argentina. Etymology. Derived from the type locality of densissima, Olivos, Buenos Aires of Argentina.

26. papuana (Pace, 2000: 161), comb. n. (Tinotus). Distribution: Papua New Guinea. 27. planula (Notman, 1920: 724), sp. rev., comb. n. (Tinotus). Distribution: USA. = parvicornis (Casey, 1911: 69), syn. n. (Tinotus), nec. Fauvel, 1900: 248 (Aleochara). = densiventris (Casey, 1911: 70) (Tinotus), nec. Bernhauer, 1906: 346 (Aleochara), nec. Casey, 1906: 158 (Baryodma).

28. refusa (Hanley, 2002: 454), comb. n. (Tinotus). Distribution: Mexico.

29. riodejaneirensis nom. n. [for eidmanni (Scheerpeltz, 1936: 528) (Tinotus), nec. Scheerpeltz, 1929: 137 (Aleochara)]. Distribution: Brazil (Rio de Janeiro).

Etymology. Derived from Rio de Janeiro, the capital city of Brazil and the type locality of this species.

30. robertopacei nom. n. [for major (Pace, 1986: 107) (Tinotus), nec. Fairmaire, 1858: 737 (Aleochara), nec. Eichelbaum, 1912: 176 (Aleochara)]. Distribution: South Africa, Tanzania, Kenya.

Etymology. Dedicated to Mr. Roberto Pace who first described this species.

31. rougemonti (Pace, 1993: 116), comb. n. (Tinotus). Distribution: China (Sichuan, Xinjiang).

32. rougemontiana (Pace, 1999a: 152), comb. n. (Tinotus). Distribution: China (Shaanxi, Sichuan, Yunnan).

33. surrubicunda nom. n. [for rufipennis (Cameron, 1939: 558) (Tinotus), nec. Stephens, 1832: 161 (Aleochara), nec. Erichson, 1839: 162 (Aleochara)]. Distribution: India (Uttar Pradesh, Uttarranchal), Nepal. 
Etymology. Combination of the Latin prefix sur meaning above or upper and the Latin adjective rubicunda meaning red in referring to the reddish body of this species. 34. takashii sp. n. Distribution: Japan (central Honshû).

35. taprobanensis (Likovský, 1984: 4), comb. n. (Tinotus). [replacement name for Aleochara minutissima Kraatz, 1859: 19]. Distribution: Sri Lanka, Malaysia (Penang), Himalaya.

= minutissima Kraatz, 1859: 19 (Aleochara).

36. thailandensis (Pace, 1992: 260), comb. n. (Tinotus). Distribution: Thailand.

37. trisecta (Casey, 1906: 321), comb. n. (Tinotus). Distribution: Canada, USA.

= fimbriata (Casey, 1911: 15) (Acrimea).

= pallida (Casey, 1911: 65) (Tinotus).

= brunnea (Casey, 1911: 65) (Tinotus), nec. Motschulsky, 1860: 582 (Caladera).

= binaria $($ Casey, 1911: 66) (Tinotus).

= lateralis $($ Notman, 1821: 154) (Tinotus).

38. uttariana nom. n. [for castanea (Cameron, 1939: 559) (Tinotus), nec. Motschulsky, 1858: 239 (Aleochara)]. Distribution: India (Uttar Pradesh), Nepal, China (Sichuan). Etymology. Derived from the type locality of castanea, Uttar Pradesh, India. 39. vietnamensis (Pace, 2001: 143), comb. n. (Tinotus). Distribution: Vietnam. 40. zairensis (Pace, 1986: 107), comb. n. (Tinotus). Distribution: Zaire.

\section{Genus Aleochara Gravenhorst, 1802}

\section{Subgenus Aleochara Gravenhorst, 1802: 67.}

1. derougemonti nom. n. [for rougemonti Pace, 2011: 68 (Aleochara), nec. Pace, 1993: 116 (Tinotus)]. Distribution: Venezuela.

Etymology. Dedicated to Mr. Guillaume de. Rougemont as the older specific epithet for this species.

2. vietnamiana nom. n. [for vietnamensis Pace, 2013b: 376 (Aleochara), nec. Pace, 2001: 143 (Tinotus)]. Distribution: Vietnam.

Etymology. Small change of the he older specific epithet for this species, meaning "of Vietnam".

\section{Subgenus Xenochara Mulsant \& Rey, 1874: 60.}

1. natalicola nom. n. [for natalensis Klimaszewski, 1993: 67 (Aleochara), nec. Pace, 1986: 107 (Tinotus)]. Distribution: South Africa.

Etymology. Combination of Natal, the type locality of this species, and the Latin suffix cola meaming inhabitor. 